\title{
Mycoplasma penetrans sp. nov., from the Urogenital Tract of Patients with AIDS
}

\author{
SHYH-CHING LO, ${ }^{1 *}$ MICHAEL M. HAYES, ${ }^{1}$ JOSEPH G. TULLY,${ }^{2}$ RICHARD YUAN-HU WANG, ${ }^{1}$ \\ HITOSHI KOTANI, ${ }^{1}$ PHILLIP F. PIERCE, ${ }^{3}$ DAVID L. ROSE, ${ }^{2}$ AND JAMES WAI-KUO SHIH ${ }^{4}$ \\ American Registry of Pathology, Department of Infectious and Parasitic Disease Pathology, Armed Forces Institute of \\ Pathology, Washington, D.C. 20306-6000'; Laboratory of Molecular Microbiology, National Institute of Allergy \\ and Infectious Diseases, Frederick, Maryland 21710²; HIV Clinical Program, Georgetown University Hospital, \\ Washington, D.C. 20007-21973; and Department of Transfusion Medicine, Warren Grant Magnuson \\ Clinical Center, National Institutes of Health, Bethesda, Maryland $20892^{4}$
}

\begin{abstract}
An unusual mycoplasma, which was isolated from the urine of a human immunodeficiency virus-positive male homosexual patient, has an elongated flask shape and two unique sharply divided internal compartments. The tiplike compartment is densely packed with fine granules, and the body compartment is loosely filled with coarse granules consistent with ribosomal structures. The organism has properties of adherence, hemadsorption, and cytadsorption and invades many different types of mammalian cells. Adhesion and penetration apparently involve the terminally located tiplike structure. Cholesterol is required for growth, and the mycoplasma ferments glucose and hydrolyzes arginine, but does not hydrolyze urea. The results of DNA homology studies revealed that this organism is not genetically related to previously described mycoplasma species that have the same biochemical properties. The results of serologic studies demonstrated that this organism is antigenically distinct from all previously described mycoplasmas. We propose that this new mollicute species should be named Mycoplasma penetrans sp. nov. The type strain is strain GTU-54-6A1 (= ATCC 55252).
\end{abstract}

A total of 13 members of the class Mollicutes have been isolated from humans $(5,14,35)$. The two most common isolation sites are respiratory and urogenital tracts $(5,35)$, although isolation from synovial fluids of patients with arthritis (23) and isolation from other anatomical sites have also been reported $(15,26,28)$.

The most common mycoplasmas in human urogenital tracts are Mycoplasma hominis and Ureaplasma urealyticum (10, 35). Mycoplasma fermentans, Mycoplasma genitalium, Mycoplasma spermatophilum, Mycoplasma primatum, Mycoplasma salivarium, and Mycoplasma pneumoniae are less common $(5,14,35,37)$. The frequency of isolation of urogenital mycoplasmas depends in part on the group of individuals studied. Sexual activity, as well as multiple sexual partners, increases the rate of isolation (25). The isolation rates for urogenital mycoplasmas are also different in heterosexual and homosexual males (16).

To date, there has been no systematic study of the urogenital mycoplasmas isolated from patients with AIDS. Our previous examination of urine samples from a small number of patients with AIDS in which we used the polymerase chain reaction and cultures for mycoplasmas revealed a high level of $M$. fermentans infection which was not found in non-AIDS controls (8). In a more comprehensive study, we isolated a previously unknown mycoplasma from urine samples from six patients with AIDS (18). In this paper we describe this organism and its unusual characteristics; we also describe our examination of its distinct biological, serological, and genetic properties, which was carried out in order to establish whether this organism should be given taxonomic status as a new mycoplasma species.

\footnotetext{
* Corresponding author.
}

\section{MATERIALS AND METHODS}

Isolation and cultivation. SP-4 medium was prepared as described below. A 10-g portion of Tryptone (Difco Laboratories, Detroit, Mich.), $5.3 \mathrm{~g}$ of peptone (Difco), and $3.5 \mathrm{~g}$ of mycoplasma broth base (BBL Microbiology Systems, Cockeysville, Md.) were dissolved in $750 \mathrm{ml}$ of deionized water. The solution was sterilized by autoclaving it at $121^{\circ} \mathrm{C}$ for 25 min and then cooled to room temperature. A 1-ml portion of $5 \mathrm{~N} \mathrm{NaOH}$ was added to adjust the $\mathrm{pH}$ to 7.4 , and the basal medium was supplemented with the following sterile components: $180 \mathrm{ml}$ of fetal bovine serum (Sigma Chemical Co.) that had been previously heated at $56^{\circ} \mathrm{C}$ for $1 \mathrm{~h}, 50 \mathrm{ml}$ of CMRL 1066 (10×; without glucose or arginine; GIBCO Laboratories, Grand Island, N.Y.), $35 \mathrm{ml}$ of a $20 \%$ solution of fresh yeast extract (Fleischman's lyophilized yeast; prepared in our laboratory), $10 \mathrm{ml}$ of a $10 \%$ glucose (Sigma) solution, $10 \mathrm{ml}$ of a $20 \%$ yeastolate (Difco) solution, $4 \mathrm{ml}$ of a $0.5 \%$ phenol red (Sigma) solution, $5 \mathrm{ml}$ of a solution containing $10^{5} \mathrm{U}$ of polymyxin B (Sigma) per $\mathrm{ml}, 10 \mathrm{ml}$ of a $1 \%$ thallium acetate (Sigma) solution, and $1 \mathrm{ml}$ of a solution containing $10^{5} \mathrm{U}$ of penicillin (Sigma) per ml. The final $\mathrm{pH}$ was $7.4 \pm 0.1$. SP-4 solid medium was prepared by adding 10 $\mathrm{g}$ of agarose (type VII; Sigma) to the basal medium prior to autoclaving. The sterile basal medium was cooled to $45^{\circ} \mathrm{C}$, and the supplements (prewarmed to $45^{\circ} \mathrm{C}$ ) were added. Portions $(5 \mathrm{ml})$ of medium were poured into $60-\mathrm{mm}$ petri dishes, and the petri dishes were kept at room temperature overnight (38).

Urine samples from patients were collected in sterile containers (the "clean-catch" method was not used) and were shipped on ice by overnight courier to our laboratory. A 50-ml portion of urine was centrifuged at $3,500 \times g$ for 15 min at $4^{\circ} \mathrm{C} ; 45 \mathrm{ml}$ of the supernatant was discarded, and the sediment was resuspended. The resulting suspension was diluted in SP-4 broth in a 10 -fold dilution series from $10^{-1}$ to $10^{-5}$ in two sets of polystyrene culture tubes $(12$ by $75 \mathrm{~mm}$ ). 
One set of tubes was used for aerobic incubation at $37^{\circ} \mathrm{C}$ with the medium $\mathrm{pH}$ at 7.4, and the other set was used for anaerobic incubation in GasPak jars (BBL) at $37^{\circ} \mathrm{C}$ with the $\mathrm{pH}$ of the medium adjusted to 8.0 (the $\mathrm{CO}_{2}$ generated in the GasPak system lowered the $\mathrm{pH}$ to approximately 7.4).

The broth cultures were examined daily for color changes. Preparations whose color changed were subcultured in SP-4 broth and on SP-4 solid medium. Pure cultures of different isolates were obtained by using triple filter cloning as described below. An early-passage broth culture was filtered through a syringe filter (pore size, $0.2 \mu \mathrm{m}$ ) and 10-fold serial dilutions were made in SP-4 broth. The filtered and diluted cultures were streaked onto SP-4 solid medium. Single colonies were excised from the SP-4 solid medium and inoculated into SP-4 broth. This procedure was repeated three times (32). The triple-cloned strain which was used in this study was strain GTU-54-6A1 ${ }^{\mathrm{T}}$ ( $\mathrm{T}=$ type strain). This strain was passed five times in SP-4 broth without antibiotics and was examined for cell wall formation by using electron microscopy (EM).

Morphology. We examined the morphology of organisms in broth cultures by dark-field microscopy and by EM, using both negative staining procedures and ultrathin sectioning of organism pellets (19). We examined the morphology of colonies on solid medium by phase-contrast microscopy and by light microscopy, using Dienes stain.

Adhesion to glass and plastic surfaces. Strain GTU-54-6A1 ${ }^{\mathrm{T}}$ was grown aerobically in glass and plastic tissue culture flasks in SP-4 broth at $37^{\circ} \mathrm{C}$. Cultures were examined daily by phase-contrast microscopy.

Biochemical and biological properties. Glucose fermentation, arginine hydrolysis, urea hydrolysis, susceptibility to digitonin, phosphatase activity, tetrazolium chloride reduction, and film and spot formation were determined by using previously described procedures $(2,4,11)$. Hemadsorption of guinea pig erythrocytes, rabbit erythrocytes, and human type $\mathrm{O}$ Rh-negative erythrocytes by colonies on SP-4 solid medium was tested as previously described (20). Cytadsorption of a human $\mathrm{CD}_{4}^{+}$lymphocyte cell line (cell line CEM [ATCC CCL 119]) and cytadsorption of a human monocytic cell line (cell line U937 [ATCC CRL 1593]) by colonies on SP-4 solid medium were also tested (22).

Filtration studies. Aliquots of an SP-4 broth culture of strain GTU-54-6A1 ${ }^{\mathrm{T}}$ were filtered through a series of membranes with average graded pore sizes of $800,450,300,200$, and $100 \mathrm{~nm}$. An unfiltered aliquot of the culture was used as a control. The unfiltered aliquot and each filtered aliquot were titrated in 10-fold serial dilutions in SP-4 broth, and the resulting preparations were incubated at $37^{\circ} \mathrm{C}$ to determine the number of color-changing units (CCU) in each aliquot. The highest dilution that showed an acidic change after 2 weeks of incubation was considered to be the end point of the CCU titration.

Sterol requirement. The effect of cholesterol on strain GTU-54-6A1 ${ }^{\mathrm{T}}$ growth was determined by first adapting the mycoplasma to grow in serum-free SP-4 broth supplemented with $1 \%$ bovine serum fraction (30). The mycoplasma was then inoculated into serum-free SP-4 broth supplemented with $1 \%$ albumin, $0.01 \%$ Tween $80,10 \mu \mathrm{g}$ of palmitic acid per $\mathrm{ml}$, and varying amounts of cholesterol $(0,1,5,10$, and 20 $\mu \mathrm{g} / \mathrm{ml}$ of medium) (30). The growth of the mycoplasma under these conditions was compared with the growth of the mycoplasma in serum-free SP-4 medium supplemented with $1 \%$ bovine serum fraction. Growth was quantified by measuring the amounts of protein present in mycoplasma pellets after centrifugation of 10-day cultures.
Tissue culture studies. Attachment, invasion, and cytopathic effects on tissue culture cells by strain GTU-54-6A1 ${ }^{\mathrm{T}}$ in vitro were examined by using Vero monkey kidney cells, mouse NIH 3T3 fibroblasts, transformed human embryo kidney cells (cell line ATCC CRL 1572), cervical carcinoma cells (HeLa cells), normal human umbilical endothelial cells, cell line CEM (= ATCC CCL 119) human $\mathrm{CD}_{4}{ }^{+}$lymphocytes, and cell line U937 (= ATCC CRL 1593) human histiocytic cells. Approximately $10^{7} \mathrm{CFU}$ of strain GTU-54$6 \mathrm{~A} 1^{\mathrm{T}}$ was inoculated into each $75-\mathrm{cm}^{2}$ flask culture of monolayer cells or suspension culture (cell lines CEM and U937). For attachment and invasion studies, the cultures were incubated at $37^{\circ} \mathrm{C}$ in an atmosphere containing $5 \% \mathrm{CO}_{2}$ for 24 to $48 \mathrm{~h}$ and then fixed for EM examination with $2 \%$ glutaraldehyde in phosphate-buffered saline $(\mathrm{pH} 7.4)$ overnight at $4^{\circ} \mathrm{C}$. The cytopathic effects of the organism on the cultured cells were observed after 1 week of incubation.

Serological tests. We prepared hyperimmune antisera to the mycoplasmas listed in Table 1 . Some of these antisera were prepared as part of the National Institutes of Health mycoplasma reference reagent program (7). The methods which were used to prepare antisera to the remaining mycoplasmas have been described elsewhere (36). Hyperimmune rabbit antiserum against strain GTU-54-6A1 ${ }^{\mathrm{T}}$ was prepared similarly. Disk growth inhibition tests (6) were performed with suspensions of strain GTU-54-6A1 $1^{\mathrm{T}}$ cells grown at $37^{\circ} \mathrm{C}$ in SP-4 broth medium. The suspensions were usually diluted 1:50 or 1:100 and then plated onto SP-4 solid medium. When the medium appeared to be dry, paper disks saturated with $0.25 \mathrm{ml}$ of undiluted mycoplasma antiserum were placed onto the surfaces, and the plates were incubated anaerobically at $37^{\circ} \mathrm{C}$ in the GasPak system. The sizes of zones of colony inhibition around the disks were recorded after an incubation period of 14 days (6). The plate epi-immunofluorescence antibody test was performed by using a direct method (9) and mycoplasma colonies which had developed on SP-4 solid medium. The colonies were stained with appropriate dilutions (usually 1:10 to 1:60) of fluoresceinconjugated antisera to the mycoplasmas listed in Table 1.

DNA. The guanine-plus-cytosine $(\mathrm{G}+\mathrm{C})$ content of the DNA from strain GTU-54-6A1 ${ }^{\mathrm{T}}$ was determined by measuring the temperature of melting point for hyperchomatic shift (24). For the melting point assays in this study, M. fermentans $(\mathrm{G}+\mathrm{C}$ content, $27.6 \mathrm{~mol} \%)$ and Bacillus circulans $(\mathrm{G}+\mathrm{C}$ content, $35.8 \mathrm{~mol} \%$ ) were used as standards.

\section{RESULTS}

Morphology. Dark-field microscopy of SP-4 broth cultures revealed long filamentous chains of rod-shaped organisms. Branching of the filamentous chains was observed occasionally. Organisms grown in SP-4 broth were examined by EM after either ultrathin sectioning or direct negative staining with phosphotungstic acid. Most organisms were rodlike with flask-shaped features (Fig. 1). Only occasional branching structures were found. The cell wall-free organisms were bound by a single three-layer unit membrane. Nearly all of the organisms had two distinct compartments (Fig. 1A). One compartment at the flask-shaped narrowing smaller end of the cell contained densely packed fine granules. The other compartment in the flask-shaped broader body contained loosely packed coarse granules. Ultrathin sectioning of the organisms and transmission EM also revealed two distinct compartments (Fig. 1B). The densely packed smaller end and the more loosely packed body of each cell were readily distinguished. The coarse granules in the body compartment 
TABLE 1. Mycoplasma strains and antisera used in serological tests

\begin{tabular}{|c|c|}
\hline Strain (origin) & Source $^{a}$ \\
\hline \multicolumn{2}{|l|}{ Mycoplasma agalactiae $\mathrm{PG}^{\mathrm{T}}$} \\
\hline Mycoplasma alkalescens $\mathrm{D} 12^{\mathrm{T}}$ & ..MS-LMM \\
\hline Mycoplasma alvi Ilsley ${ }^{\mathrm{T}}$. & ..MS-LMM \\
\hline Mycoplasma anatis $1340^{\mathrm{T}}$. & ..NIH \\
\hline Mycoplasma anseris $1219^{\mathrm{T}}$ & ..MS-LMM \\
\hline Mycoplasma arginini $\mathrm{G} 230^{\mathrm{T}}$. &. NIH \\
\hline Mycoplasma arthritidis PG6 ${ }^{\mathrm{T}}$ & ..NIH \\
\hline Mycoplasma bovigenitalium PG1 & ..NIH \\
\hline Mycoplasma bovirhinis $\mathrm{PG} 43^{\mathrm{T}}$. & ..NIH \\
\hline Mycoplasma bovis Donetta ${ }^{\mathrm{T}}$.. & ..MS-LMM \\
\hline Mycoplasma bovoculi $\mathrm{M} 165 / 69^{\mathrm{T}}$ & ..MS-LMM \\
\hline Mycoplasma buccale $\mathrm{CH} 20247^{\mathrm{T}}$ & ..NIH \\
\hline Mycoplasma californicum ST-6 ${ }^{\mathrm{T}}$. & ..MS-LMM \\
\hline Mycoplasma canadense $275 C^{T}$ & ..MS-LMM \\
\hline Mycoplasma canis $\mathrm{PG}^{\mathrm{T}}{ }^{\mathrm{T}} \ldots$. &. NIH \\
\hline Mycoplasma capricolum Californ & MS-LMM \\
\hline Mycoplasma caviae $\mathrm{G} 122^{\mathrm{T}} \ldots \ldots .$. & ..MS-LMM \\
\hline Mycoplasma cavipharyngis $117 \mathrm{C}^{\mathrm{T}}$ & ..MS-LMM \\
\hline Mycoplasma citelli $\mathrm{RG}-2 \mathrm{C}^{\mathrm{T}}$. & ..MS-LMM \\
\hline Mycoplasma cloacale $383^{\mathrm{T}}$ & ..MS-LMM \\
\hline Mycoplasma collis $58 \mathrm{~B}^{\mathrm{T}} \ldots$ & ..MS-LMM \\
\hline Mycoplasma columbinasale $694^{\mathrm{T}}$ & .MS-LMM \\
\hline Mycoplasma columbinum MMP-1 &. MS-LMM \\
\hline Mycoplasma columborale MMP-4 & .MS-LMM \\
\hline Mycoplasma conjunctivae HRC58 & ..MS-LMM \\
\hline Mycoplasma cricetuli $\mathrm{CH}^{\mathrm{T}} \ldots$ & .MS-LMM \\
\hline Mycoplasma cynos $\mathrm{H} 831^{\mathrm{T}}$ & .MS-LMM \\
\hline Mycoplasma dispar $462 / 2^{\mathrm{T}}$. & .MS-LMM \\
\hline Mycoplasma edwardii PG $24^{\mathrm{T}}$ & MS-LMM \\
\hline Mycoplasma ellychniae ELCN-1 & .MS-LMM \\
\hline Mycoplasma equigenitalium $\mathrm{T} 37^{\mathrm{T}}$ & .MS-LMM \\
\hline Mycoplasma equirhinis $\mathrm{M} 432 / 72^{\mathrm{T}}$ & MS-LMM \\
\hline Mycoplasma fastidiosum $4822^{\mathrm{T}}$.. & MS-LMM \\
\hline Mycoplasma faucium $\mathrm{DC} 333^{\mathrm{T}}$. & ..NIH \\
\hline Mycoplasma felifaucium $\mathrm{PU}^{\mathrm{T}}$. & .MS-LMM \\
\hline Mycoplasma feliminutum Ben ${ }^{\mathrm{T}}$. & MS-LMM \\
\hline Mycoplasma felis $\mathrm{CO}^{\mathrm{T}}$. & .MS-LMM \\
\hline Mycoplasma fermentans $\mathrm{PG} 18^{\mathrm{T}}$. &. $\mathrm{NIH}$ \\
\hline Mycoplasma flocculare $\mathrm{Ms} 42^{\mathrm{T}} \ldots$ & MS-LMM \\
\hline Mycoplasma gallinaceum $\mathrm{DD}^{\mathrm{T}}$. & MS-LMM \\
\hline Mycoplasma gallinarum $\mathrm{PG}^{\mathrm{T}}$. &. NIH \\
\hline Mycoplasma gallisepticum $\mathrm{PG} 31^{\mathrm{T}}$ &. $\mathrm{NIH}$ \\
\hline Mycoplasma gallopavonis WR1 ${ }^{\mathrm{T}}$ & MS-LMM \\
\hline Mycoplasma gateae $\mathrm{CS}^{\mathrm{T}}$.. & .MS-LMM \\
\hline Mycoplasma genitalium $\mathrm{G} 37^{\mathrm{T}}$ & .MS-LMM \\
\hline Mycoplasma glycophilum $486^{\mathrm{T}}$ & MS-LMM \\
\hline Mycoplasma hominis $\mathrm{PG} 21^{\mathrm{T}}$. &. $\mathrm{NIH}$ \\
\hline Mycoplasma hyopharyngis $\mathrm{H} 3-6 \mathrm{~B}$ & MS-LMM \\
\hline Mycoplasma hyopneumoniae $\mathrm{J}^{\mathrm{T}}$ & MS-LMM \\
\hline Mycoplasma hyorhinis BTS $7^{\mathrm{T}}$. &. $\mathrm{NIH}$ \\
\hline Mycoplasma hyosynoviae $\mathrm{S} 6^{\mathrm{T}}$. & MS-LMM \\
\hline Mycoplasma iners $\mathrm{PG} 30^{\mathrm{T}} \ldots \ldots$. & NIH \\
\hline Mycoplasma iowae $695^{\mathrm{T}} \ldots$ & MS-LMM \\
\hline Mycoplasma lactucae $831-\mathrm{C} 4^{\mathrm{T}}$ & .MS-LMM \\
\hline Mycoplasma lipofaciens $\mathrm{R} 171^{\mathrm{T}}$. & MS-LMM \\
\hline Mycoplasma lipophilum $\mathrm{MaBy}$ & \\
\hline Mycoplasma lucivorax PIPN-2 ${ }^{\mathrm{T}}$. & MS-LMM \\
\hline Mycoplasma luminosum PIMN-1 & MS-LMM \\
\hline
\end{tabular}

were consistent with bacterial ribosomal structures. Most cells were 0.2 to $0.4 \mu \mathrm{m}$ wide and 0.8 to $2 \mu \mathrm{m}$ long. Prolonged culture of strain GTU-54-6A1 ${ }^{\mathrm{T}}$ in antibiotic-free SP-4 broth did not induce cell wall formation.

Cultural properties. In primary isolation cultures, an acidic color change was observed after 7 to 10 days in both
TABLE $1-$ Continued

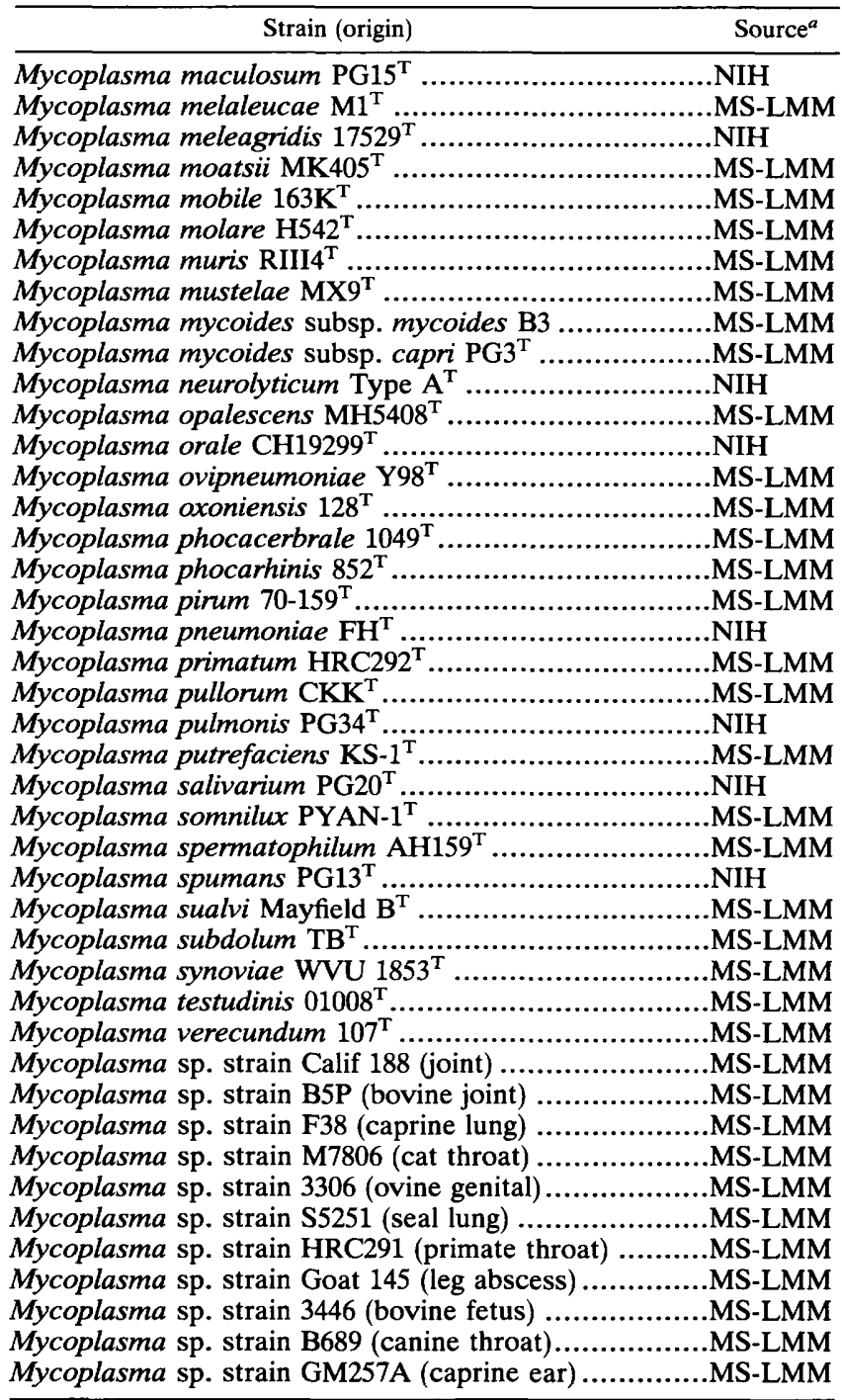

${ }^{a}$ NIH, Reference Reagent Collection of the National Institute of Allergy and Infectious Diseases (7); MS-LMM, Mycoplasma Section, Laboratory of Molecular Microbiology, National Institute of Allergy and Infectious Diseases.

aerobic and anaerobic GasPak cultures. The color changed 1 to 2 days earlier in anaerobic GasPak cultures than in aerobic cultures. A slight turbidity occurred in the supernatant, and a noticeable pellet formed in the bottom of each culture tube. Upon transfer to SP-4 solid medium, colony formation was slow; it sometimes took as long as 14 days for growth to become evident. Colonies first appeared as refractile dots and later assumed a mycoplasma morphology although some colonies lacked the dense center (yolk) of typical mycoplasma colonies. The more typical fried-egg appearance of the colonies occurred only after several passages on SP-4 solid medium, with the central embedded (yolk) area tending to remain small (Fig. 2A). Dienes stain revealed a dense center with a thinner peripheral region (Fig. 2B). During subsequent passages the time required for growth in SP-4 broth and on SP-4 solid medium decreased.

Filtration studies. Broth cultures of strain GTU-54-6A1 ${ }^{\mathrm{T}}$ with a titer of $10^{9} \mathrm{CCU} / \mathrm{ml}$ were filtered through membrane 

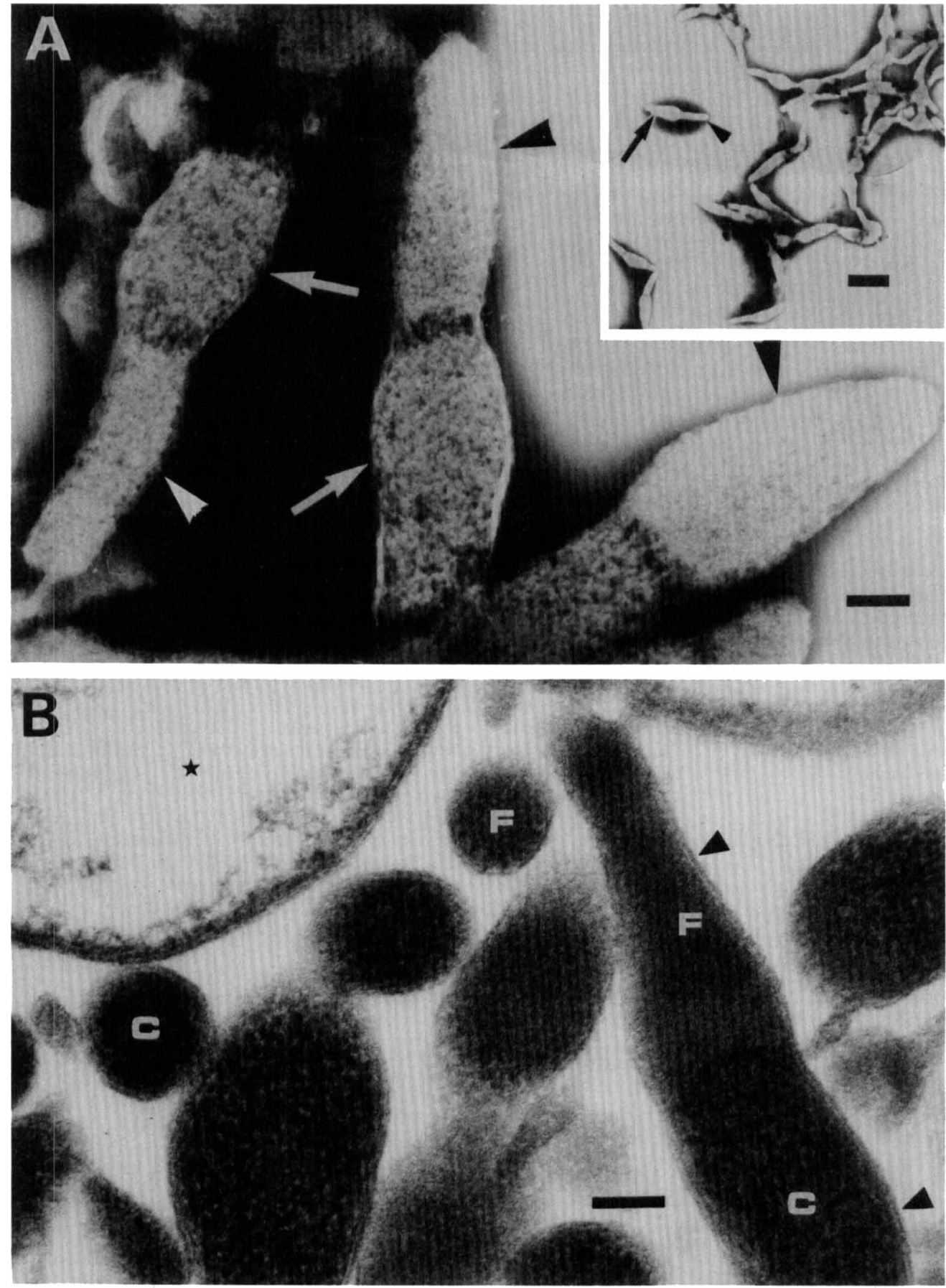

FIG. 1. Electron micrographs of $M$. penetrans. (A) Negatively stained mycoplasmas from a 5-day culture in SP-4 broth. Most organisms are rodlike with an elongated flask shape. There are two separate compartments. The tiplike compartments (arrowheads) and the body compartments (arrows) can be distinguished easily. Bar $=100 \mathrm{~nm}$. (Insert) Negative staining of mycoplasmas with two distinct compartments at a low magnification. Bar $=1,000 \mathrm{~nm}$. (B) Thin section of $M$. penetrans cells in an SP-4 broth culture after 5 days. There are two sharply divided compartments in the pleomorphic organisms after sectioning. The densely packed fine-granule compartments (F), which are located at the narrow ends of the organisms, and the coarse-granule compartments $(\mathrm{C})$ of the cell bodies are bound by a trilaminar unit membrane (arrowheads) without a cell wall structure. A large vacuole (star) is also present. Bar $=100 \mathrm{~nm}$.

filters having average pore diameters of $800,450,300,200$, and $100 \mathrm{~nm}$. Serial 10 -fold dilutions of each filtrate were made in SP-4 broth, and the resulting preparations were incubated for 2 weeks at $37^{\circ} \mathrm{C}$. The highest dilution that showed an acidic color change was considered to be the end point of the CCU titration. The filtrates contained $10^{8}, 10^{8}$, $10^{7}, 10^{7}$, and $0 \mathrm{CCU} / \mathrm{ml}$, respectively. The organisms apparently passed through the $200-\mathrm{nm}$-pore-size filter without significant retention.

Sterol requirement. The growth response of strain GTU- 

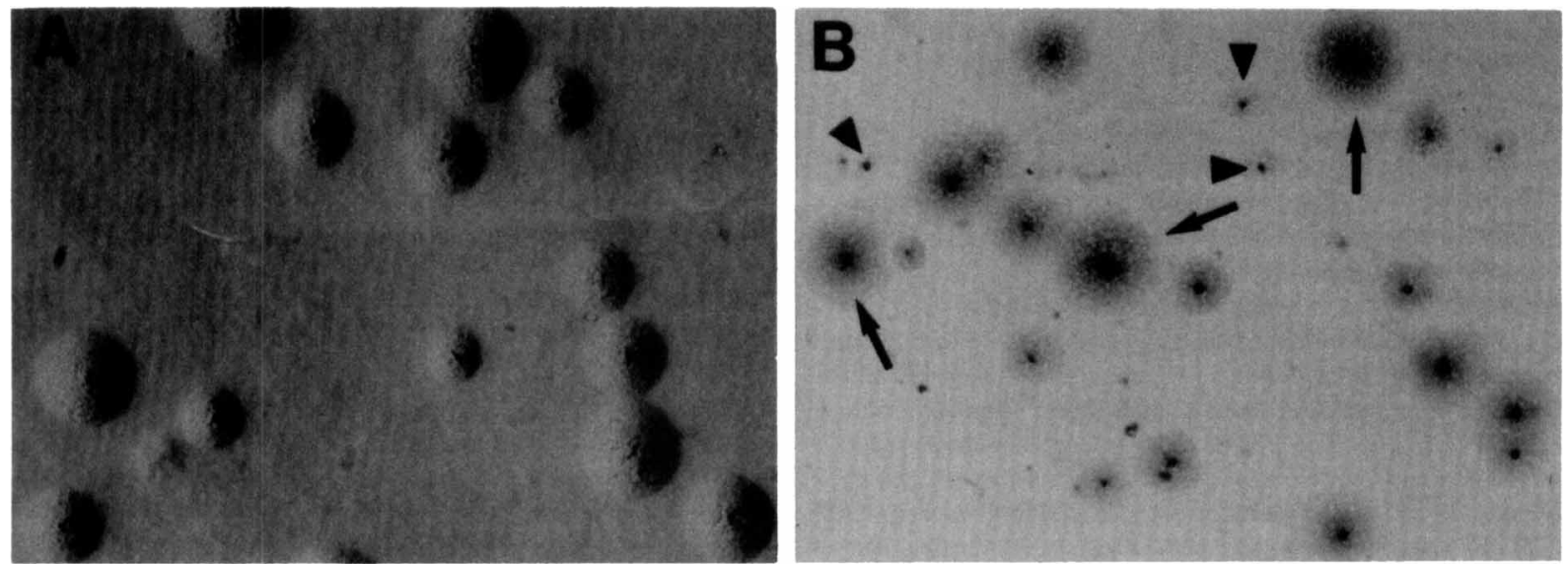

FIG. 2. $M$. penetrans colonies on an agar plate. (A) Colonies of $M$. penetrans grown for 14 days aerobically on SP-4 solid medium (1\% agarose). (B) Dienes staining of $M$. penetrans colonies. A central (agar-penetrating) area is evident in both large colonies (arrows) and small colonies (arrowheads).

54-6A1 $1^{\mathrm{T}}$ to cholesterol is shown in Table 2 . No growth was observed in serum-free basal medium or in medium containing minimal concentrations of supplemental cholesterol. Growth became evident when higher concentrations of cholesterol were added or when serum-free basal medium was supplemented with $1 \%$ bovine serum fraction.

Biochemical and biological properties. The biochemical and biological properties of strain GTU-54-6A1 ${ }^{\mathrm{T}}$ are as follows: positive for formation of fried-egg colonies, glucose fermentation and oxidation, arginine hydrolysis, cholesterol requirement, susceptibility to digitonin, phosphatase activity (aerobic and anaerobic), tetrazolium chloride reduction (aerobic and anaerobic), adhesion to glass or plastic surfaces, hemadsorption, and cytadsorption; negative for urea hydrolysis, film and spot formation, and beta-hemolysis; weak alpha-hemolysis; and $\mathrm{G}+\mathrm{C}$ content, $30.5 \mathrm{~mol} \%$. Some of the unusual biological properties of this mycoplasma have been reported previously (18). Of particular interest is the ability of this organism to both ferment glucose and hydrolyze arginine, as well as its strong adhesion, hemadsorption, and cytadsorption properties.

Serological tests. Using an immunoblot assay, Lo et al. showed that strain GTU-54-6A1 ${ }^{\mathrm{T}}$ is antigenically different from any previously described human Mycoplasma species (18). In this study, growth inhibition of strain GTU-54-6A1 ${ }^{\mathrm{T}}$ on SP-4 solid medium and the results of epi-immunofluorescence tests with antisera or conjugates (Table 1) indicated

TABLE 2. Growth response of strain GTU-54-6A1 ${ }^{\mathrm{T}}$ to cholesterol

\begin{tabular}{lcc}
\hline $\begin{array}{c}\text { Supplement(s) added } \\
\text { to serum-free } \\
\text { basal medium }\end{array}$ & $\begin{array}{c}\text { Cholesterol } \\
\text { concn }(\mu \mathrm{g} / \mathrm{ml}) \\
\text { added to medium }\end{array}$ & $\begin{array}{c}\text { Amt of protein } \\
(\mathrm{mg} / 100 \mathrm{ml})^{a}\end{array}$ \\
\hline Bovine serum fraction $(1 \%)$ & 0 (control) & 11.00 \\
None & 0 & $\mathrm{IG}^{b}$ \\
Albumin $(1 \%)$, Tween 80 & 0 & IG \\
$(0.01 \%)$, and palmitic & 1 & IG \\
acid $(10 \mu \mathrm{g} / \mathrm{ml})$ & 5 & IG \\
& 10 & 1.12 \\
\hline
\end{tabular}

a The amount of protein from a centrifuged cell pellet obtained from a $100-\mathrm{ml}$ aliquot of a broth culture after incubation at $37^{\circ} \mathrm{C}$ for 10 days.

${ }^{b}$ IG, insufficient growth. that strain GTU-54-6A1 ${ }^{\mathrm{T}}$ is serologically different from any previously described Mycoplasma sp., including Mycoplasma pirum, Mycoplasma alvi, Mycoplasma sualvi, $M y$ coplasma moatsii, Mycoplasma iowae, and $M$. fermentans, the mycoplasma species previously shown to ferment glucose and hydrolyze arginine (29). However, a number of antisera to other Mycoplasma species did show low levels of growth-inhibiting activity (zone sizes, 1 to $4 \mathrm{~mm}$ ) against strain GTU-54-6A1 ${ }^{\mathrm{T}}$. In most instances, this possible antigenic relationship could not be confirmed in epi-immunofluorescence tests with agar colonies of strain GTU-54-6A1 ${ }^{\mathrm{T}}$. In reciprocal assays in which we used Mycoplasma species whose antisera had shown some growth inhibition activity against strain GTU-54-6A1 ${ }^{\mathrm{T}}$, hyperimmune rabbit antiserum against strain GTU-54-6A1 ${ }^{\mathrm{T}}$ failed to inhibit the growth of any of these mycoplasma species.

DNA. The $\mathrm{G}+\mathrm{C}$ content of purified DNA of strain GTU$54-6 \mathrm{Al}^{\mathrm{T}}$ was $30.5 \mathrm{~mol} \%$, as measured by the melting point for hyperchromatic shift. In a previous study, ${ }^{32} \mathrm{P}$-labeled genomic DNA or molecularly cloned DNA from strain GTU-54-6A1 ${ }^{\mathrm{T}}$ was used as a probe to hybridize with DNAs from other human and animal mycoplasmas that are known to utilize both glucose and arginine. In these tests, strain GTU-54-6A1 ${ }^{\mathrm{T}}$ was shown to be genetically distinct from all of these mycoplasmas (18).

Tissue culture studies. EM examination of ultrathin sections of strain GTU-54-6A1 ${ }^{\mathrm{T}}$-infected cultures of Vero monkey kidney cells, mouse NIH 3T3 fibroblasts, transformed human embryo kidney cells (cell line ATCC CRL 1572), cervical carcinoma cells (HeLa cells), normal human umbilical endothelial cells, cell line CEM human $\mathrm{CD}_{4}{ }^{+}$lymphocytes, and cell line U937 human monocytic cells revealed prominent cell attachment and invasion. Attachment to cell surfaces apparently led to invasion of some strain GTU-54$6 \mathrm{Al}^{\mathrm{T}}$ cells into the cytoplasm (Fig. 3A). The invading organisms were oriented on the target cells with their densely packed tiplike structures. Insertion of a tiplike spearhead structure into a cell produced a deep invagination of the cell membrane (Fig. 3B). The entire organism could completely penetrate into the cytoplasm. Most of the resulting intracellular mycoplasmas were in membrane-bound vesicles in the cytoplasm (Fig. 3C). While many cells that were heavily infected with strain GTU-54-6A1 ${ }^{\mathrm{T}}$ still appeared to be intact, cell disruption and necrosis followed 

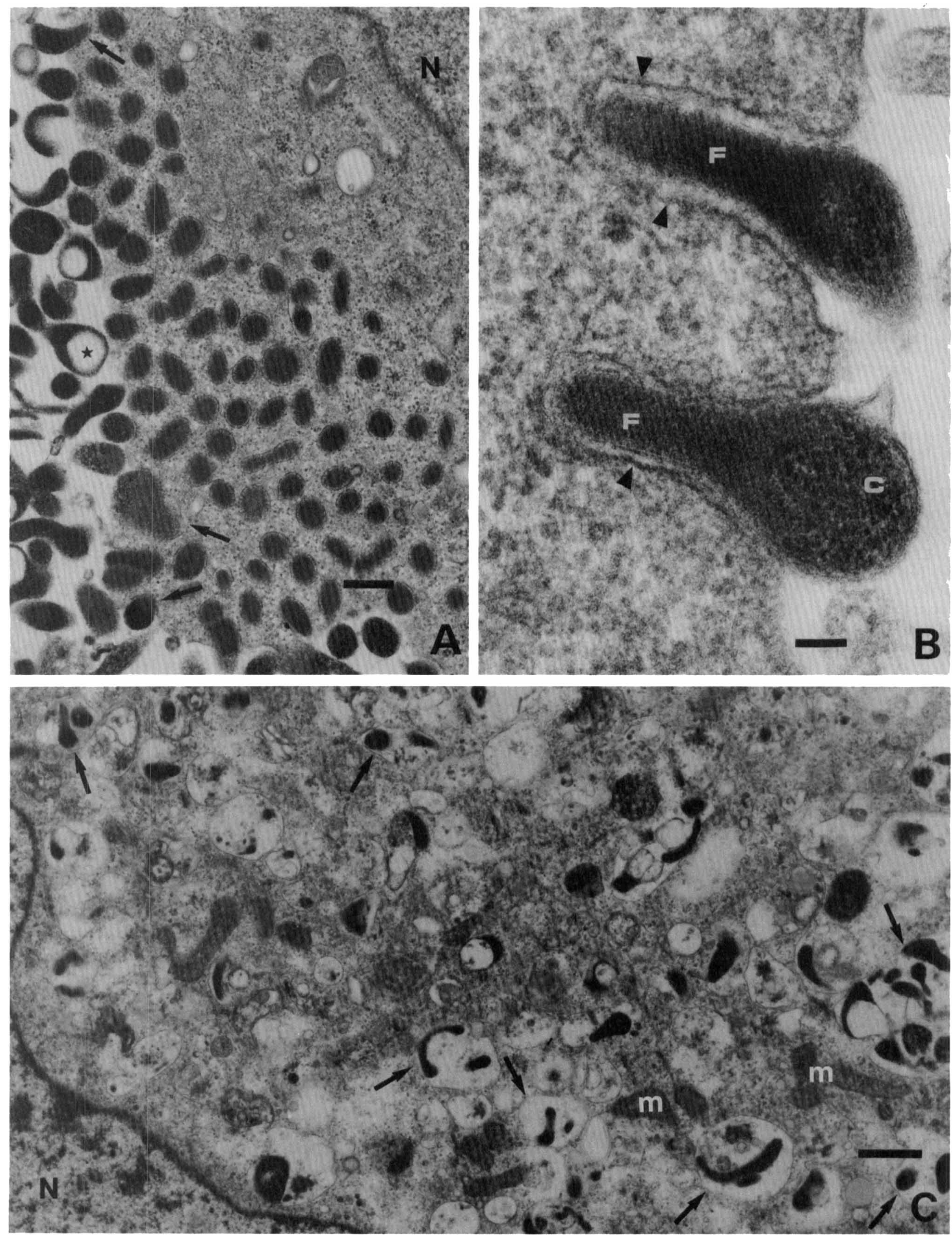
FIG. 3. Invasion of $M$. penetrans into mammalian cells. (A) Numerous $M$. penetrans cells adhering to the cell surface and invading the cytoplasm of a human embryo kidney cell in a 4-day culture. The nucleus $(\mathrm{N})$ of the kidney cell is labeled. Most of the organisms inside the cytoplasm were visible as cross-sections of their inserted tiplike structures. This section also shows some organisms lining up on the cell surface with their tiplike structures (arrows) beginning to invade the cytoplasm. An extracellular organism with a vacuole (star) is also indicated. Bar $=250 \mathrm{~nm}$. (B) Longitudinal section of mycoplasmas invading a mammalian cell. The organisms on the cell surface insert their tiplike structures (densely packed with fine granules $[\mathrm{F}]$ ) into the cytoplasm. The body compartments containing loosely packed coarse granules (C) remain outside. Bar $=100 \mathrm{~nm}$. (C) Human embryo kidney cell containing numerous mycoplasma cells which have apparently completely invaded the cytoplasm. Most of the intracellular organisms are in clusters inside membrane-bound vesicles (arrows). The nucleus $(\mathrm{N})$ and mitochondria $(\mathrm{m})$ of the cell are labeled. Bar $=1,000 \mathrm{~nm}$.

extensive invasion (details will be reported separately). In general, monolayer cultures were more susceptible to infection than suspension cultures.

\section{DISCUSSION}

We have described previously the results of a preliminary study of the morphological, biochemical, biological, and serological characteristics of the new mycoplasma strain GTU-54-6A1 ${ }^{\mathrm{T}}$, which was originally isolated from the urine of a human immunodeficiency virus-positive male homosexual patient (18). In this paper we present additional information which shows that strain GTU-54-6 $\mathrm{Al}^{\mathrm{T}}$ is a taxonomically distinct mycoplasma. Subsequently, the same mycoplasma was successfully isolated from urine samples from five additional human immunodeficiency virus-positive patients with AIDS (18). These isolates are morphologically, serologically, and genetically indistinguishable from strain GTU-54-6A $1^{\mathrm{T}}$. Details of a comparison of these strains will be presented elsewhere.

The most distinctive morphological feature of strain GTU$54-6 \mathrm{~A} 1^{\mathrm{T}}$ is the apparent division of this organism into fine-granule and coarse-granule compartments. The fine granules are densely packed in the tiplike structure, and the coarse granules, which are consistent with ribosomal structures, fill the body compartment. This unique characteristic of compartmentation has not been reported previously in mycoplasmas, with the possible exception of $M$. iowae (27). Strain GTU-54-6A1 ${ }^{\mathrm{T}}$ is superficially morphologically similar to $M$. pneumoniae, $M$. genitalium, Mycoplasma gallisepticum, $M$. alvi, and $M$. sualvi by virtue of its flask shape and tiplike structure $(1,3,12,13,37)$. Adhesion on the surfaces of mammalian cells and invasion of the cytoplasm by strain GTU-54-6A1 ${ }^{\mathrm{T}}$ apparently involve the specialized tiplike structure.

Strain GTU-54-6 $\mathrm{A1}^{\mathrm{T}}$ is unusual biochemically in that it both ferments glucose and hydrolyzes arginine. This combination of biochemical properties is found in only a few previously described species $(M$. alvi, $M$. sualvi, $M$. iowae, $M$. moatsii, $M$. pirum, and $M$. fermentans) (29). In a previous study, DNA homology analyses revealed that there is no close genetic relationship between strain GTU-54-6A1 ${ }^{\mathrm{T}}$ and these species (18).

The biological properties of strain GTU-54-6A1 ${ }^{\mathrm{T}}$ that are of particular interest are the ability to adhere to glass and plastic surfaces, the ability to hemadsorb strongly, and the ability to cytadsorb strongly. These characteristics are known to be associated with in vivo pathogenicity of $M$. pneumoniae and $M$. gallisepticum $(21,31,33,34,39,40)$. Intracellular invasion is an even more unusual property that has been documented only recently in one other species of mycoplasma, $M$. fermentans. $M$. fermentans is associated with pathological lesions in tissues of patients with AIDS and non-AIDS patients with an acute fulminant illness (17).

The isolation of strains identical to strain GTU-54-6A1 ${ }^{\mathrm{T}}$ from several patients with AIDS, combined with the abovementioned characteristics associated with in vivo virulence in mycoplasmas, raises the possibility that this organism may be of clinical importance. Until additional studies are performed, we can only speculate as to what role this organism may play in AIDS or other pathological conditions in humans. We are currently performing studies to resolve this question.

We believe that the evidence which we present above demonstrates that strain GTU-54-6A1 ${ }^{\mathrm{T}}$ is a new species and propose that this species should be named Mycoplasma penetrans (pen'e. trans. L.adj. penetrans, penetrating, a penetrant, referring to the unusual ability of this mycoplasma to penetrate into mammalian cells). The taxonomic description below summarizes the properties of this new species.

Description of Mycoplasma penetrans sp. nov. The cells are flask shaped and are divided into two compartments, one with a fine-granule appearance and the other with a coarsegranule appearance. The elongated cells grow in broth cultures as chains; branching is rarely observed. The cells lack true cell walls and do not produce a cell wall when they are cultured in the absence of penicillin. On solid medium typical mycoplasma colonies are formed. Growth in broth and growth on solid media occur under both aerobic and anaerobic conditions. In broth cultures there is a noticeable turbidity, and a pellet is formed in the bottom of each culture tube. The cells adhere to glass and plastic surfaces. Strong hemadsorption and cytadsorption are observed with colonies on solid medium.

Glucose is fermented, and arginine is hydrolyzed. Urea is not hydrolyzed. Cholesterol is required for growth.

Serologically unrelated to previously described species and strains of mycoplasmas.

Genetically unrelated (as determined by DNA hybridization) to mycoplasmas that have been shown previously to both ferment glucose and hydrolyze arginine. The $\mathrm{G}+\mathrm{C}$ content of the DNA is $30.5 \mathrm{~mol} \%$, as measured by the melting point for hyperchromatic shift.

The type strain is strain GTU-54-6A1; this strain has been deposited in the American Type Culture Collection as strain ATCC 55252.

\section{ACKNOWLEDGMENTS}

We thank P. B. Newton III and J. F. Rodriquez, Division of Molecular Pathobiology and American Registry of Pathology, for technical support and D. J. Wear, Department of Infectious and Parasitic Diseases Pathology, Armed Forces Institute of Pathology, for assistance in preparation of the manuscript.

The study was supported in part by U.S. Public Health Service grant AI-31830 from the National Institute of Allergy and Infectious Diseases. 


\section{REFERENCES}

1. Allen, T. C., J. O. Stevens, E. R. Florance, and R. O. Hampton. 1970. Ultrastructure of Mycoplasma gallisepticum isolate 1056. J. Ultrastruct. Res. 33:318-331.

2. Aluotto, B. B., R. G. Wittler, C. O. Williams, and J. E. Faber. 1970. Standardized bacteriologic techniques for the characterization of Mycoplasma species. Intl. J. Syst. Bacteriol. 20:35-58.

3. Biberfeld, G., and P. Biberfeld. 1970. Ultrastructural features of Mycoplasma pneumoniae. J. Bacteriol. 102:855-861.

4. Bradbury, J. M. 1977. Rapid biochemical tests for characterization of Mycoplasmatales. J. Clin. Microbiol. 5:531-534.

5. Cassell, G. H., and B. C. Cole. 1981. Mycoplasmas as agents of human disease. N. Engl. J. Med. 304:80-89.

6. Clyde, W. A., Jr. 1964. Mycoplasma species identification based upon growth inhibition by specific antisera. J. Immunol. 92:958-965.

7. Cunningham, S., and J. E. Nutter (ed.). 1975. NIAID catalog of research reagents. Publication (NIH) 75-899. National Institutes of Health, Bethesda, Md.

8. Dawson, M. S., R. Wang, M. Hayes, D. Armstrong, D. Budzko, R. Kundsin, and S.-C. Lo. 1991. Detection and isolation of Mycoplasma fermentans from urine of patients with AIDS. abstr. G-4, p. 134, Abstr. 91st Gen. Meet. Am. Soc. Microbiol. 1991. American Society for Microbiology, Washington, D.C.

9. DelGiudice, R. A., N. F. Robillard, and T. R. Carski. 1967. Immunofluorescence identification of mycoplasma on agar by use of incident illumination. J. Bacteriol. 93:1205-1209.

10. Fiacco, V., M. J. Miller, E. Carney, and W. J. Martin. 1984. Comparison of media for isolation of Ureaplasma urealyticum and genital Mycoplasma species. J. Clin. Microbiol. 20:862-865.

11. Freundt, E. A., B. E. Andrews, H. Erno, M. Keinzer, and F. T. Black. 1973. The sensitivity of Mycoplasmatales to sodiumpolyanethol-sulfonate and digitonin. Zentralbl. Bakteriol. Parasitenkd. Infektionskr. Hyg. Abt. 1 Orig. 255:104-112.

12. Gourlay, R. N., S. G. Wyld, and R. H. Leach. 1977. Mycoplasma alvi, a new species from bovine intestinal and urogenital tracts. Int. J. Syst. Bacteriol. 27:86-96.

13. Gourlay, R. N., S. G. Wyld, and R. H. Leach. 1977. Mycoplasma sualvi, a new species from the intestinal and urogenital tracts of pigs. Int. J. Syst. Bacteriol. 28:289-292.

14. Hill, A. C. 1991. Mycoplasma spermatophilum, a new species isolated from human spermatozoa and cervix. Int. J. Syst. Bacteriol. 41:229-233.

15. Hummell, D. S., S. J. Anderson, P. F. Wright, G. H. Cassell, and K. B. Waites. 1987. Chronic recurrent multifocal osteomyelitis: are mycoplasmas involved? N. Engl. J. Med. 317:510-511.

16. Lee, Y.-H., B. Rosner, S. Alpert, N. J. Fiumara, and W. H. McCormack. 1978. Clinical and microbiological investigation of men with urethritis. J. Infect. Dis. 138:798-803.

17. Lo, S.-C., M. S. Dawson, D. M. Wong, P. B. Newton III, M. A. Sonoda, W. F. Engler, R. Y.-H. Wang, J. W.-K. Shih, H. J. Alter, and D. J. Wear. 1989. Identification of Mycoplasma incognitus infection in patients with AIDS: an immunohistochemical, in situ hybridization and ultrastructural study. Am. J. Trop. Med. Hyg. 41:601-616.

18. Lo, S.-C., M. M. Hayes, R. Y.-H. Wang, P. F. Pierce, H. Kotani, and J. W.-K. Shih. 1991. A newly discovered adherent and invasive mycoplasma from a patient with AIDS. Lancet 338: $1415-1418$.

19. Lo, S.-C., J. W.-K. Shih, P. B. Newton III, D. M. Wong, M. M. Hayes, J. R. Benish, D. J. Wear, and R. Y. Wang. 1989. Virus-like infectious agent (VILA) is a novel pathogenic myco- plasma: Mycoplasma incognitus. Am. J. Trop. Med. Hyg. 41:586-600.

20. Manchee, R. J., and D. Taylor-Robinson. 1968. Hemadsorption and hemagglutination by mycoplasmas. J. Gen. Microbiol. 50:465-478.

21. Manchee, R. J., and D. Taylor-Robinson. 1969. Utilization of neuraminic acid receptors by mycoplasmas. J. Bacteriol. 98: 914-919.

22. Manchee, R. J., and D. Taylor-Robinson. 1969. Studies on the nature of receptors involved in attachment of tissue culture cells to mycoplasmas. Br. J. Exp. Pathol. 50:66-75.

23. Mardh, P. A., F. J. Nilsson, and A. Bjelle. 1973. Mycoplasmas and bacteria in synovial fluid from patients with arthritis. Ann. Rheum. Dis. 32:319-325.

24. Marmur, J., and P. Doty. 1962. Determination of the base composition of deoxyribonucleic acid from its thermal denaturation temperature. J. Mol. Biol. 5:109-118.

25. McCormack, W. M., Y.-H. Lee, and S. H. Zinner. 1973. Sexual experience and urethral colonization with genital mycoplasmas: a study in normal men. Ann. Intern. Med. 78:696-698.

26. McDonald, J. C., and D. L. Moore. 1988. Mycoplasma hominis meningitis in a premature infant. Pediatr. Infect. Dis. J. 7:795798.

27. Mirsalimi, S. M., S. Rosendal, and R. T. Julian. 1989. Colonization of the intestine of turkey embryos exposed to Mycoplasma iowae. Avian Dis. 33:310-315.

28. Munday, P. E., P. M. Furr, and D. Taylor-Robinson. 1981. The prevalence of Ureaplasma urealyticum and Mycoplasma hominis in the cervix and anal canal of women. J. Infect. 3:253-257.

29. Razin, S., and E. A. Freundt. 1984. The mycoplasmas, p. 740-770. In N. R. Krieg and J. G. Holt (ed.), Bergey's manual of systemic bacteriology, vol. 1. The Williams \& Wilkins Co., Baltimore.

30. Razin, S., and J. G. Tully. 1970. Cholesterol requirement of mycoplasmas. J. Bacteriol. 102:306-310.

31. Somerson, N. L., W. D. James, B. E. Walls, and R. Chanock. 1967. Growth of Mycoplasma pneumoniae on a glass surface. Ann. N.Y. Acad. Sci. 143:384-389.

32. Subcommittee on the Taxonomy of Mollicutes. 1979. Proposal of minimal standards for description of new species of the class Mollicutes. Int. J. Syst. Bacteriol. 29:172-180.

33. Tajima, M., T. Nunoya, and T. Yagihashi. 1979. An ultrastructural study of the interaction of Mycoplasma gallisepticum with the chicken tracheal epithelium. J. Vet. Res. 40:1009-1014.

34. Taylor-Robinson, D., and R. J. Manchee. 1967. Adherence of mycoplasmas to glass and plastic. J. Bacteriol. 94:1781-1782.

35. Taylor-Robinson, D., and W. H. McCormack. 1980. The genital mycoplasmas. N. Engl. J. Med. 302:1003-1010.

36. Tully, J. G., M. F. Barile, D. G. F. Edward, T. S. Theodore, and H. Erno. 1974. Characterization of some caprine mycoplasmas, with proposals for new species, Mycoplasma capricolum and Mycoplasma putrefaciens. J. Gen. Microbiol. 85:102-120.

37. Tully, J. G., D. Taylor-Robinson, D. L. Rose, R. M. Cole, and J. M. Bove. 1983. Mycoplasma genitalium, a new species from the human urogenital tract. Int. J. Syst. Bacteriol. 33:387-396.

38. Tully, J. G., R. G. Whitcomb, H. F. Clark, and D. L. Williamson. 1977. Pathogenic mycoplasmas: cultivation and vertebrate pathogenicity of a new spiroplasma. Science 195:892-894.

39. Wilson, M. H., and A. M. Collier. 1976. Ultrastructural study of Mycoplasma pneumoniae in organ culture. J. Bacteriol. 125: 332-339.

40. Zucker-Franklin, D., M. Davidson, and L. Thomas. 1966. The interaction of mycoplasmas with mammalian cells. I. HeLa cells, neutrophils, and eosinophils. J. Exp. Med. 124:521-532. 